\title{
CHALLENGES TO IDENTIFY
}

THE VULNERABILITY OF MIGRANT WOMEN ON THE SOUTHERN BORDER OF EUROPE: CONTRIBUTIONS FROM BIOGRAPHICAL NARRATIVES

Submitted: October, 2019.

Accepted: Septemeber, 2020. UDK: 314.745.3-054.73-055.2 DOI 10.3935/ljsr.v28i1.328

Inmaculada AntolinezDomínguez ${ }^{1}$ orcid.org/0000-0003-3321-0795 Social Work Area Department of Labor Law and Social Security University of Cadiz, Spain

\section{Esperanza} Jorge-Barbuzano ${ }^{2}$ ABSTRACT

In the 1980s, the Southern Frontier of Spain became one of the southern borders of the European Union after Spain entered into the European Economic Community (EEC). On the African continent, the Spanish cities of Ceuta and Melilla that border with Morocco are physically separated from Spain by the Mediterranean Sea. Those two cities became a privileged enclave for immigration control, but also for the detection of vulnerable conditions of the migrant population. This paper has a double objective: to describe the action research developed in the Center for the Temporary Residence of Immigrants in Ceuta and to analyze 49 biographical interviews with women residents of the Center within the framework of said

orcid.org/0000-0002-8261-166X

University of Cádiz, Spain

Ključne riječi:

migrant women;

vulnerability;

southern European border; biographical narratives

1 Inmaculada Antolinez-Domínguez, Lecturer in Social Work, e-mail: inmaculada.antolinez@uca.es

2 Esperanza Jorge-Barbuzano, Post-doctoral researcher, e-mail: maspebeleten@ gmail.com 
action research. The results show the diversity of situations of vulnerability in which migrant women can find themselves in this border context. Hence, it is important to rethink the intervention to avoid secondary victimization within critical and humanistic models of intervention. This work, precisely, addresses the design of a tool for biographical narratives from the perspectives of integral health and care.

\section{INTRODUCTION}

Over the past few decades, the migration of the African population in transit to Europe, has been crossing Morocco to reach Spain. In the 1980s, both politically and socially, migration became a current issue. With the entry of Spain into the European Economic Community (EEC) in 1986, due to its location with respect to Africa, the country became a southern European border ${ }^{3}$ with the African continent.

Given the aforementioned geostrategic location of Spain, a migration policy has been developed which is aligned with the needs of Europe and which is based upon the blocking of migration routes and the increasing externalisation of its borders (Frelick, Kysel and Podkul, 2016; Rais, 2016; Papageorgiou, 2018). From the 1990s, border control led to: 1) the construction of fences in Ceuta (1995) and Melilla (1998), and the deployment of inter-fencing of concertina-type lines in surfaces consisting of wire with cutting edges in 2005 (Amnesty International, 2015); 2) the implementation of the "hot returns» to Morocco that implies returning those who cross into Spanish territory back to Morocco without having applied the established protocols to confirm whether or not the person is a minor or a potential asylum seeker (Spanish Ombudsman, 2016) ${ }^{4}$; 3) since the end of the 1990s, the implementation of Detention Centres for Foreigners (hereinafter, termed CIE which is the Spanish acronym) that are institutions which, in fact, exercise the deprivation of liberty, whereby those persons who have initiated a sanctioning file that can propose their expulsion from Spanish territory are retained; and 4) the Centres for the Temporary Residence of Immigrants (hereinafter, termed CETI which is the Spanish acronym) in the Spanish Autonomous Cities of Ceuta and Melilla in 2000, which are for people who enter either of both territories in an irregular manner. The centres are conceived as mechanisms of first provisional reception, which are intended to provide basic socio-sanitary services and benefits to the group of immigrants in the facilities themselves or through referral to other centres. The detection of situations that are susceptible to asylum

3 For the purpose of this article, the southern border refers to the following Spanish regions: Ceuta, Melilla, coasts of Andalusia and the Levante area, as well as the Canary Islands.

4 This practice, which contravenes multiple international treaties and agreements, was legalised in the last Organic Law 4/2015, of March 30, on the protection of citizen security. 
applications, minorities of age or links to trafficking in human beings is included in the intervention procedures of these centres.

In this context, there has also been an increase in arrivals. Thus, in 2010 there were 3,632 entries that reached 64,120 in 2018, according to data from the Association for the Defence of Human Rights in Andalusia (APDHA, 2019). This notable increase is due, among other reasons, to 1 ) the increased risk involved in the central Mediterranean route, which goes to Italy from Lybia; 2) the agreements between Libya and Italy with the aim of controlling migration in the African territory, and 3) the reluctance of the Italian prime minister to receive ships carrying rescued migratory persons. On the other hand, the Eastern route has lost its flux because of the agreement signed by Turkey and the European Union (EU) in 2016, in which the country assumed migration control and interruption functions.

On the other hand, in terms of profiles, migration to Spain in the 1980s and 1990s consisted mainly of Moroccans and to a lesser extent Algerians. In the first years of the 21st century, the Senegalese population gained importance and, subsequently, other sub-Saharan countries such as Nigeria, Cameroon and Mali (and recently Guinea Conakry and Ivory Coast). For the past few years, Syria has also joined the exodus as a result of the conflict in that country (APDHA, 2016).

Finally, reports from specialised organisations mention the situations of high vulnerability regarding specific locations. Some sources note the difficulties in the country of origin due to war conflicts, environmental disasters or impoverishment (Naudé, 2010). Others report the difficulties of the migratory route by land at its various crossings, including the border between Algeria and Morocco (Euro-Mediterranean Human Rights Network, 2013; Bacheletet, 2018). Some of these sources have a special focus on the human rights violations that are experienced in Morocco, with an emphasis on the consequences regarding physical and psychological health (De Haas, 2008; Doctors Without Borders, 2010, 2013; Conseil National des Droits de l'Homme, 2013;). Along these lines of reportage are those that highlight the violence, specifically against women, who are often subjected to sale, exchange, multiple aggressions and violations (Hadjab, 2017; Morcillo, de la Fuente and Sotomayor, 2017; Jorge and Antolinez, 2018). Finally, several organisations point to the southern Spanish border as an enclave of human rights violations in general (Amnesty International, 2015; CEAR ${ }^{5}$, 2017; APDHA, 2019). Hence, the aim of the present study is to pay attention to this context and to the people who must endure it. To do this, we developed an action research work. The management committee of CETI requested one of the co-authors, as a professional of a non-profit organisation (NGO) that is specialising in migration, to provide support in conducting interviews

5 Spanish acronym for the Spanish Refugee Assistance Commission. 
that are designed with the aim of detecting situations of vulnerability of a sample of resident women.

\section{AIM AND PURPOSE}

Regarding what is stated above, we asked ourselves what kind of situations of vulnerability are experienced by women who cross the southern border by Ceuta. On the other hand, from the point of view of the intervention, we ask ourselves how to design a tool that would allow interviews to be carried out in a short time and that would avoid possible re-victimization. After the experience of conducting biographical interviews with 49 women residing at the CETI, we proposed the analysis based on three research objectives: 1 ) show the challenges that the context poses for the detection of such situations of vulnerability; 2 ) offer results of different situations of vulnerability and, 3) make visible the contributions that a methodological proposal, that is designed for care, can offer to the interview technique.

\section{The importance of detecting situations of vulnerability for the design of corresponding itineraries}

Vulnerability is a concept that is traditionally understood from the perspective of two dimensions: an external dimension related to risk exposure, and an internal dimension that is based on the ability to deal with the risk exposure. According to this logic, "vulnerable groups are then those groups that are most likely to suffer harm and, if they do suffer harm, then they recover but in a worse condition than before, or they do not recover at all» (Morondo, 2016: 210), hence the importance of generating protection strategies or strengthening the resilience in these groups. Along these lines, Fineman (2010), based on the term «responsive state» proposes that the State must assure individuals or groups access to institutions and opportunities to strengthen resilience processes and the ability of the individuals to face vulnerability.

On the other hand, from the International Covenant on Economic, Social and Cultural Rights (1966), and the European Social Charter (1961), the category of "vulnerability state» and the term "vulnerable groups» began to be extended by being incorporated into the discourse of International organisations such as the United Nations, ECLAC or the Red Cross (Baylos, 2015). Regarding the case in the present study, the migrant population is classified as one of these groups due to, among other reasons, the limitation of social rights, which implies its potential for administrative irregularity. 
Taking this into account, from the "responsive state», we can point out three institutionalised protection channels that are aimed at the migrant population in the case of Spain. One of these channels is access to a demand for international protection. According to the Geneva Convention of 1951, a person who is recognised as a refugee is: "any person who, due to well-founded fears of being persecuted on the grounds of race, religion, nationality, political opinions, belonging to a certain social group, gender or sexual orientation, who is outside the country of his or her nationality and cannot, or because of such fears, does not want to avail himself or herself of the protection of that country».

In the European regulations concerning asylum and refuge ${ }^{6}$, minors, unaccompanied minors, disabled persons, elderly people, pregnant women, parents with only minor children, victims of trafficking in human beings, persons with psychological disorders and persons who have suffered torture, rape or other serious forms of psychological, physical or sexual violence would be identified as being particularly vulnerable. On the other hand, both General Recommendation No. 19 of the CEDAW Committee, DEVAW and the Inter-American Convention to prevent, punish and eradicate violence against women admit that violence against women does occur, both in the public and private spheres, and that «the State is responsible for this type of violence when it is exercised by a non-state agent and due diligence is not taken by implementing the necessary measures to prevent, investigate and punish any act of violence against women» (Miguel, 2016:175). Hence, in the Spanish context, Law $12 / 2009$, of 30 October, regulating the right to asylum and subsidiary protection incorporates persecution for reasons of gender and sexual orientation (Art. 3), but without specifying the reasons that would express some mention of particularly vulnerable groups such as minors and victims of human trafficking.

The second channel of institutionalised protection is aimed at precisely those individuals who are possible victims of trafficking in human beings, a crime within which the following must occur:

..the recruitment, transportation, transfer, harbouring or receipt of persons, by means of the threat or use of force or other forms of coercion, of abduction, of fraud, of deception, of the abuse of power or of a position of vulnerability or of the giving or receiving of payments or benefits to achieve the consent of a person having control over another person, for the purpose of exploitation. Exploitation shall include, at a minimum, the exploitation of the prostitution of

6 Article 20.3 of Directive 2011/95 / EU; Directive 2013/32 / EU; Directive 2013/33 / EU; Regulation 603/2013 / EU on EURODAC and; Regulation 604/2013 / EU on the determination of the Member State responsible for examining the application (Dublin III). 
others or other forms of sexual exploitation, forced labour or services, slavery or practices similar to slavery, servitude or the removal of organs ${ }^{7} . .$.

In the Spanish context, following the Framework Protocol for the Protection of Victims of Human Beings of the «Ministry of the Interior» (hereinafter, the Framework Protocol), the agents that can identify a person as a victim of trafficking are the Law Enforcements, and it is essential that the victim should tell their life story. Social organisations can detect possible victims, in addition to providing the information they deem necessary, accompany the victims and offer them adequate resources pertaining to the comprehensive assistance proposal they need. Once identified, the person has the possibility of accessing the recovery and protection channels that, according to article 59bis of Organic Law 4/2000, of 11 January, on the rights and freedoms of foreigners in Spain and their social integration, would be summarised in: 1) comprehensive assistance for physical, psychological and social restoration; 2 ) the granting of a period of recovery and reflection; and, 3) the issuance of a residence permit when the competent authority considers it necessary for the victim to stay in the territory. However, one of the most harshly criticised facts is precisely that, in practice, access to these measures can only be guaranteed as long as the possible victims agree to collaborate in the investigation and act as witnesses in the legal proceedings against their human traffickers (Spanish Ombudsman, 2012). The second way, due to any personal situation, is more difficult to access. Thus, according to the figures of the Intelligence Centre against Terrorism and Organised Crime, in Spain only $5.7 \%$ of people detected at risk were identified as victims of trafficking for sexual exploitation in 2017.

Finally, the third channel would be the one that is directed towards a migrant population of unaccompanied minors. The Framework Protocol on certain actions in relation to Unaccompanied Foreign Minors (13 October, 2014) defines them as «the foreigner under the age of eighteen years who is a national of a State to which the European Union regime does not apply, and who arrives in a Spanish territory without an adult who is responsible for them». From the assumption of the best interests of the child, different actions can be carried out. On the one hand, the return of the child to his country of origin, with his family if possible, or on the other, delivery of the child into a protection centre. Other channels, once the "Fiscal Ministry" and the "Child Protection Service» were informed, would be the processing the request for asylum by the minor; the identification of the minor at risk and/or their link to human trafficking; or the declaration of the situation of helplessness, where the pro-

7 Protocol to Prevent, Suppress and Punish Trafficking in Persons Especially Women and Children, supplementing the United Nations Convention against Transnational Organized Crime, 2000, Article 3 
tection of the minor would be assumed by a public entity, thus accessing a specific protection situation.

\section{The case of the CETI in Ceuta: Challenges in detecting situations of vulnerability}

The Autonomous City of Ceuta and the Autonomous City of Melilla are two Spanish territories which are located in the north of the African continent and are bordering with Morocco (Figure 1). These two cities are surrounded by a fenced perimeter that is under border control. Likewise, both cities are separated from the Iberian Peninsula by the Mediterranean Sea, which facilitates a geographical confinement for the migrant population. Both are a key point of entry to Spain on the Western Mediterranean Route.

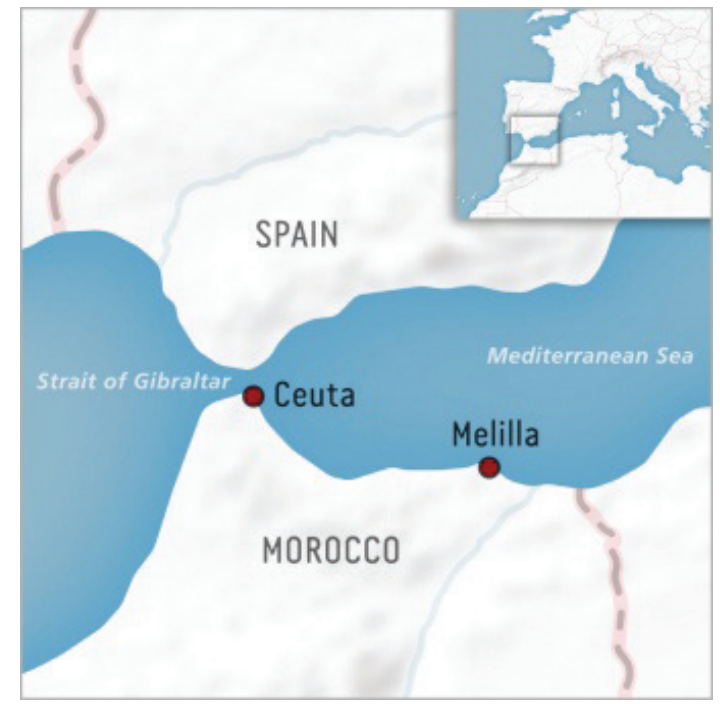

Figure 1. Ceuta and Melilla map ${ }^{8}$

As aforementioned, every migrant who enters an Autonomous City in an irregular manner is transferred to the CETI. Due to the exceptional situation of confinement experienced in Ceuta in general, and in the CETI in particular, the time that a migrant spends in the institution is especially important in order to be able to detect any situation of vulnerability that would allow an individual to access an itinerary of protection.

8 Source: https://www.opensocietyfoundations.org/voices/why-violence-flaring-europe-s-border-crossings 
The technical team of the CETI, together with the social organisations that work in the centre, undertake interviews and hold workshops to inform the residents of the centre about their rights and to favour the detection and transfer to specialised resources of those individuals who are considered to be in a situation of "vulnerability». In this context, the term "vulnerable" means any person with special care needs, either because of his or her state of health, personal or family circumstances, circumstances that make him or her a possible asylum seeker, or his/her possible identification as a victim of trafficking. Transfers to the peninsula are made via host resources that are managed by NGOs within the framework of the Humanitarian Attention Program ${ }^{9}$. In the case that a minor is detected, he or she would follow the aforementioned procedure for his or her protection.

Although the CETI of Ceuta could be an exceptional space for the detection of this type of circumstances, the data reveal that there are still important challenges that require reporting, and these are presented below.

\section{Asylum requests are blocked by the exception status of Ceuta}

As reflected in several reports (CEAR, 2014, 2017; Amnesty International, 2015, 2016; APDHA, 2018), the number of asylum concessions made in the context is barely significant. As noted by the above literature, if asylum is requested in Ceuta, even if an individual has been admitted for processing, that person is not allowed to move to the peninsula. For this reason, from 2010 to 2017, 15 sentences of Superior Courts of Justice of Madrid and Andalusia were issued, thus affirming that asylum seekers «may be subject to identity and document controls, but in no case may such causes prevent their right of free movement» (CEAR, 2017:23). Due to this fact, only $11.6 \%$ of the individuals who were residents in the CETI were asylum seekers, and none of them were sub-Saharan (CEAR, 2017:24). Likewise, at the asylum office that opened in March 2015 at the El Tarajal border post in Ceuta, no request for asylum was registered through the border procedure.

However, according to the Spanish UNHCR committee, «70\% of people from sub-Saharan Africa who try to jump the fence could be asylum seekers» (Migreurop and GADEM, 2015:50). The distinction that has been created between economic migrants and refugees seems to have its highest expression at the southern European border. Thus, in relation to dark-skinned African people, «in the place, the Spanish

9 Royal Decree 441/2007, of 3 April, which approves the regulations governing the direct giving of grants to entities and organisations that carry out humanitarian assistance actions for immigrants (BOE 19/4/2007). 
authorities do not consider them as people in need of international protection and therefore they justify rejections at the border» (APDHA, 2016:30). In this way, situations of persecution, escaping natural disasters or conflicts as serious as those that plague Somalia, South Sudan, Mali, Nigeria or the Democratic Republic of the Congo are all avoided.

\section{Constraints on the use of speech that would especially affect potential victims of trafficking}

On the other hand, no data exist regarding identification by the police of victims of trafficking in the CETI of Ceuta (CEAR, 2017). In order to understand this fact, we consider it important to note the role that "speech constraints" can play in this context (Antolinez and Jorge, 2018) and which can be summarised as:

a) It is essential to avoid or minimise the re-victimisation that may result from the evocation of the painful episodes that we locate in their stories. It is noteworthy that it is precisely these episodes that are requested to be narrated in order to be identified as "victims" of trafficking and to be provided with access to assistance and protection.

b) It is common to find testimonies that indicate that an individual is forbidden to tell some part of their experiences or to provide specific information about people or places. The threat is directed towards the relatives of the individual at the origin or at the destination, and towards the individuals themselves. Again, these data are given greater importance by the Law Enforcements for the prosecution of the crime.

c) Specifically in the case of potential victims of foreign origin, the administrative situation of irregularity is an added factor regarding their vulnerability at their destination, and which may lead to a failure by the individual to initiate a police-driven process because the individual is in fear of being deported.

d) In the case under study, we add the location as a speech constraint. One of the difficulties for women to perceive themselves as victims of trafficking is that, although they may have experienced aggression and sexual violence along their route, they may have not yet experienced any exploitation because Ceuta is not a final destination for them. In addition, the coexistence in the CETI of the possible victims of trafficking with the people who control them within the network creates a situation where the individual cannot significantly rely on a security framework. 


\section{The difficulty in recognising a minority group}

Many unaccompanied minors are sub-Saharan who declare themselves as being of legal age in order to avoid being made available to the child protection services in Ceuta. The age of majority allows them to be referred to CETI, whereby they will be presented with more opportunities of being transferred to other parts of Spain within the aforementioned Humanitarian Attention Program. In addition, criticisms are added regarding the identification mechanisms that are used on minority groups by way of a bone test using magnetic resonance imaging (MRI) to determine migrant age. This methodology has been widely questioned by the scientific community, as well as by UNHCR (2009), with a warning about its lack of precision by not accounting for racial, ethnic, nutritional, environmental, psychological and cultural aspects that influence development and child growth.

Finally, Amnesty International (2016) indicates those cases in which young women do not recognise themselves as being minors while they are linked to human trafficking networks. The subsequent transfer of such minors to the peninsula, as with any other migrant of legal age in an irregular situation (but without any protection), creates the increased risk of the exploitation of an individual who has been located by the networks.

\section{METHODOLOGY}

Taking into account these challenges, the present study has led us to explore the methodological tools that could support the processes of detecting situations of vulnerability, regarding the aforementioned protection categories.

In this work, we focus on a qualitative analysis of the information that was produced during 49 interviews with migrant women who were residing in the CETI in Ceuta ${ }^{10}$. These interviews were carried out between 3/8/2016 and 29/9/2016 at the request of the CETI management to an NGO professional who is also a co-author of the present paper.

The specific aim of the present study was to locate the necessary indicators for the detection of situations of vulnerability. For this, it was proposed to hold meetings with women in the form of interviews. The duration of the interviews was 1

10 At all times, the undertaking of the present study has received the informed consent of the individuals who are involved and the participating institution, with the assumption that the results shall be presented solely for scientific purposes and for the improvement of professional practice. Likewise, from the beginning, a commitment was assumed both with the institution and with the participating women to safeguard the anonymity and personal data of the women interviewed. Finally, the interviews were analyzed for scientific research purposes when the CETI management authorized it, hence the writing of this document took 2 years after the interviews were carried out. 
to 2 hours in a private space. The selection was made directly by the CETI given the criteria that the woman presented indicators of vulnerability in the first interview with her. Likewise, there was a coordinated work of both other CETI units and the social organizations that work within it, as we will mention later. The characteristics of the people who were interviewed are shown in Table 1.

Table 1. Profiles of women interviewed in the CETI in Ceuta

\begin{tabular}{|c|c|c|c|}
\hline & & Freq. & Percentage \\
\hline \multirow{4}{*}{ NATIONALITIES } & $\begin{array}{l}\text { Guinea Conakry, West } \\
\text { Africa }\end{array}$ & 37 & $75.51 \%$ \\
\hline & $\begin{array}{l}\text { Nigeria (or suspected } \\
\text { of being from } \\
\text { Nigeria), West Africa }\end{array}$ & 10 & $\begin{array}{l}20.40 \% .1 \text { identified as being } \\
\text { Nigerian; } 3 \text { claim to be from Malawi; } \\
3 \text { from Sudan; } 1 \text { from Liberia; } 1 \text { from } \\
\text { Kenya, and } 1 \text { from Eritrea }\end{array}$ \\
\hline & Syria, Middle East & 1 & $2.04 \%$ \\
\hline & $\begin{array}{l}\text { Ivory Coast, West } \\
\text { Africa }\end{array}$ & 1 & $2.04 \%$ \\
\hline \multirow{4}{*}{ AGE } & $18-24$ & 33 & $67.34 \%$. \\
\hline & $25-29$ & 7 & $14.28 \%$ \\
\hline & $30-35$ & 6 & $12.24 \%$ \\
\hline & +35 & 1 & $2.04 \%$ \\
\hline \multirow{3}{*}{$\begin{array}{l}\text { ECONOMIC } \\
\text { SITUACION }^{11}\end{array}$} & Poverty Conditions & 36 & $73.46 \%$ \\
\hline & $\begin{array}{l}\text { Modest Standard of } \\
\text { Living }\end{array}$ & 8 & $16.32 \%$ \\
\hline & No data & 5 & $10.20 \%$ \\
\hline \multirow{6}{*}{$\begin{array}{l}\text { EDUCATION } \\
\text { LEVEL }\end{array}$} & No studies & 11 & $22.44 \%$ \\
\hline & Primary & 22 & $44.89 \%$ \\
\hline & Secondary & 10 & $20.40 \%$ \\
\hline & High school & 2 & $4.08 \%$ \\
\hline & University & 2 & $4.08 \%$ \\
\hline & No data & 2 & $4.08 \%$ \\
\hline \multirow{3}{*}{ RELIGION } & Muslim & 37 & $75.51 \%$ \\
\hline & Christian & 9 & $18.36 \%$ \\
\hline & No data & 3 & $6.12 \%$ \\
\hline TOTAL & & & 49 women \\
\hline
\end{tabular}

11 The category of "Poverty Conditions» refers to the situation when respondents used the term to describe their situation at source. The category of «Modest Standard of Living» refers to a situation of deprivation in context, but such situations are not defined by the person as Poverty Condition. 
It is noteworthy that in the CETI in Ceuta, there can be no minors since they would go to a specialised centre. Likewise, the centre had the proper personnel with responsibility for detection and accompaniment in asylum cases. Therefore, the aim at the time of analysing the information in this study was placed on the need to detect possible situations of trafficking in human beings, an issue for which the institution was also becoming prepared in 2016.

To do this, we designed a model card that would allow us to locate cases that are susceptible to intervention, by using the indicators for identification of victims of human trafficking that are established in the Framework Protocol. This tool, in turn, proposes to avoid secondary victimisation by favouring a narrative accompaniment process based on care (Noddings, 1988), addressing the experiences of participants from an integral health perspective, rather than risking any potential personal damage to the individual. The file itself allowed, to the best of our knowledge, a first systematisation of the discourse in a structured manner (McAdams, 1993) (See Figure 2). With these criteria, we sought to achieve the following:

a) Facilitate the ordering of the life story by using chapters with a timeline and three human silhouettes that represent the person interviewed in their country of origin, during the journey, and at the time of the interview.

b) In the specific case of trafficking in human beings, every indicator that appears in the Framework Protocol will be collected (this would be mostly through pictograms, combined with text). In this way, it would be easier to understand the card by using simple icons, while allowing the interview to be guided not only in temporal terms, as indicated in the previous section, but also in terms of the key facts or milestones in the trafficking (recruitment, border crossing, documentation, contacts in Europe, etc.).

c) The fact that the route we propose to adopt concerning the lives of the individuals is focused on how their bodies are at each stage (in their origin, their pathway, and their current situation), in terms of integral health. This allows us to approach other indicators that are proposed to locate and draw in the silhouettes such factors as diseases, damages, care, or the people who allowed them such care or exercised such damage. Starting from episodes by using human silhouettes allows us to detect those individuals to whom the troubles were directed, and the individuals who were linked to any problems; the aggressions experienced in their origin, their pathway and in their current situation; pregnancies and/or abortions; the economic situation in their origin and the possibility of access to hospitals, etc. On the other hand, it allows a first approximation of what health needs may be requiring attention, and if the individual considers it to be appropriate, in which case they can be referred to the CETI medical team. 
d) Reduce the risk that we might place women in when we ask them to tell us their stories, since these women and their possible controllers do not conceive of this session as a space for the detection of trafficking in human beings, but as a review of their health and physical conditions. To this we must add that the CETI also has the support of a psychologist to accompany people during their stay.

e) Cover the various levels of training in verbal or written expression that women have, with translation support in their mother tongue, and with the use of language forms that include plastic or iconographic means.

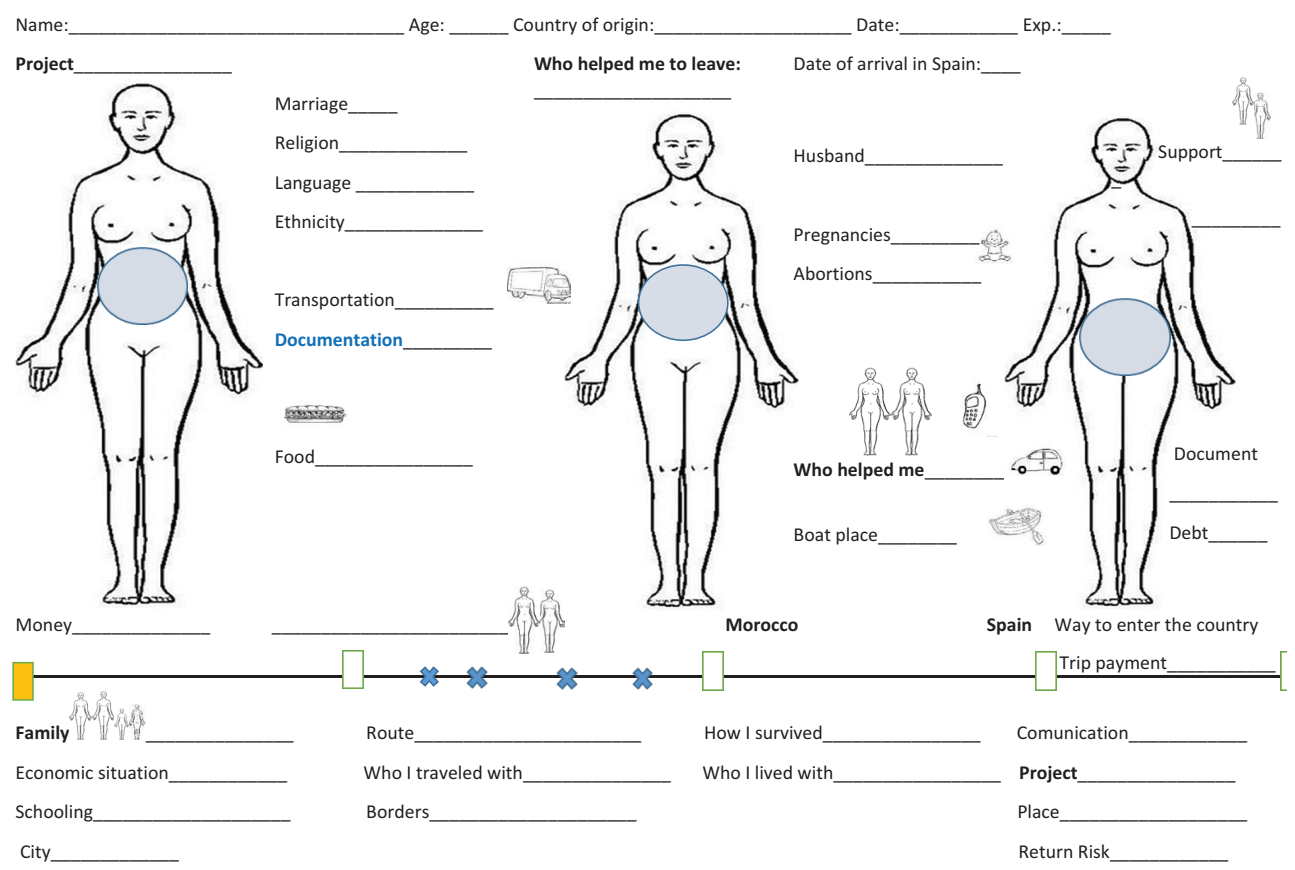

Figure 2. Sample card based on the indicators for identification of victims of human trafficking of the Framework Protocol

In this process, with the participation of the facilitator each woman produced her file in individual sessions through verbal narratives (oral and written) and visual narratives (drawings), and with the support of a CETI interpreter. The final result of the file is the story as a largely written document that can be analysed. These files were systematised, analysed and contrasted with others, by the members of the technical team of the CETI itself (a lawyer, a doctor and two social workers), as well as by the mediators of one of the NGOs (Cruz Blanca Foundation) that held weekly 
group workshops with residents, thus ensuring the proper triangulation of information (Gibbs, 2012). From the intervention approach that this work has, coordination with NGOs was also essential. For example, if it was detected that any of the women could exercise the role of controlling others, the social organization that carried out activities in the CETI was notified so that they could pay special attention to these possible indicators.

\section{RESULTS AND DISCUSSION}

Regarding the double objective of the research and action of the present study, at the time of the scientific analysis of the information, we began from the axial and open coding of the interviews (Charmaz, 2005) with respect to the warning signs of diverse situations of vulnerability.

Initially, we focused specifically on the detection of cases of possible victims of human trafficking. However, the interview model itself, based on comprehensive health and care, allowed us to locate other cases such as: a) having suffered female genital mutilation; b) fleeing from or having experienced a forced marriage; c) having experienced intra- and extra familiar sexist violence; or, d) having experienced sexual violence or other forms of violence along their migration route. These indicators, to which should be added: e) the violation of social norms or customs; f) forced sterilization; and g) sexual orientation and identity, are especially indicated in the work of Miguel (2016.) in an analysis of international protection and asylum processes from a gender perspective, hence, we find these to be of special importance.

Finally, we use the Atlas.ti 6.0 qualitative data analysis and research software to encode this information, thus obtaining code relationships, as well as their frequency and quantification (See Tables 2 and 3). 
Table 2. General indicators for identification of victims of human trafficking from the Framework Protocol ${ }^{12}$

\begin{tabular}{|c|c|c|c|}
\hline STAGE & INDICATORS & Freq. & $\%$ \\
\hline \multirow{3}{*}{ RECRUITMENT } & Vulnerable context in origin. & 44 & 89.78 \\
\hline & $\begin{array}{l}\text { Did not organise the voyage / did not know the } \\
\text { route. }\end{array}$ & 43 & 87.75 \\
\hline & Kidnapping, sentimental relationship, friendship. & 26 & 53.06 \\
\hline \multirow{3}{*}{$\begin{array}{l}\text { TRANSPORTATION, } \\
\text { TRANSFER, } \\
\text { HARBOURING and } \\
\text { RECEIPT }\end{array}$} & No documentation or hold false documentation. & 42 & 85.71 \\
\hline & $\begin{array}{l}\text { Accompanied by someone who helped them to } \\
\text { cross borders. }\end{array}$ & 40 & 81.63 \\
\hline & Difficulty in managing languages. & 49 & 100 \\
\hline
\end{tabular}

Table 3. Indicators of situations of vulnerability based on the analysis of the interview cards

\begin{tabular}{lccc}
\hline \multicolumn{1}{c}{ INDICATORS } & Freq. & \% \\
\hline Possible victim of trafficking & 41 & $\mathbf{8 3 . 6 7}$ \\
\hline Female genital mutilation $^{\prime}$ & 25 & $\mathbf{5 1 . 0 2}$ \\
\hline Sexual violence on the voyage $^{13}$ & 25 & $\mathbf{5 1 . 0 2}$ \\
\hline Forced marriage $^{13}$ & 17 & $\mathbf{3 4 . 6 9}$ \\
\hline Male violence at the origin & 13 & $\mathbf{2 6 . 5 3}$ \\
\hline Another type of violence at the origin & 5 & $\mathbf{1 0 . 2 0}$ \\
\hline Possibility of being a minor & 10 & $\mathbf{2 0 . 4}$ \\
\hline
\end{tabular}

12 In the table there are indicators that we do not include. "Recruitment» does not include "l had false information about living / working conditions» because, despite the presumption of its existence in most of the individuals, until they reach their final destination this cannot be confirmed. «Transportation, Transfer, Harbouring and Receipt» does not include «Social isolation from family or friends» because in the CETI the individuals share space with other individuals with whom they can have some family life or friendship, but we do not infer networks security as it coexists with the presence of controllers. It also does not include «Do not freely decide your place of residence and/or work» since the individuals have not yet reached their final destination. Finally, we do not include «Exploitation» indicators that are included in the Framework Protocol since, as aforementioned, this has not normally occurred when the individuals were in the CETI in Ceuta.

13 The exposed results respond to what is explicitly expressed by women. However, if we inspected the bodily samples or the previous experiences of other women, this percentage could be higher. 


\section{The multiple situations of vulnerability in the studied cases in the CETI in Ceuta}

The analysis of the information produced in the interview cards yields results that are consistent with the purpose of the design, that is, the detection of indicators for identification of victims of human trafficking. Of the 49 women who were interviewed, 83.67\% presented indicators related to both "Recruitment» and "Transportation» in their biographical narratives, but «Exploitation» was impossible to record since it had not yet occurred.

Starting with the indicators of «Recruitment», $89.78 \%$ come from an origin with a context of vulnerability, as can be seen in the data in Table 1 where economic impoverishment is one of the most important reasons for getting out of their region of origin. In addition, $67.33 \%$ represent the bulk of women with no education or with primary education, with de-schooling and illiteracy being a clear risk factor for recruitment in human trafficking, as Tuwor and Sossou (2008) note for the cases of Ghana, Nigeria and Togo. Finally, regarding the early ages in their migration process it is noteworthy that the majority (67.34\%) are between 18 and 24 years of age and $20.04 \%$ are suspected of being younger, which is consistent with the study undertaken by Omorodion (2009) in the area of Benin City in Nigeria, and that of García de Diego (2010) regarding unaccompanied minors, or the results of Hadjab (2017) on the new generations of migrants in Spain.

Secondly, following the «recruitment» indicators, $87.75 \%$ of participants note that they themselves have not organised the trip, or that they ignored the places that they passed through. The most common allusions refer to having little information about the route, the fact of going blindfolded or, simply not remembering the route on which they travelled. As for the way out of the country, more than half $(53.06 \%)$ of the participants note the figure of a boyfriend, a friend of the family or other person, thanks to whom they began the trip and continued to have a presence during the transfer, but disappearing from the narratives of the study participants once they arrived in Morocco. One of the young women, who claimed to be from Malawi, points out: "My uncle left me the money to travel and a friend of his took care of me on the way to Morocco although he could not prevent me from being raped".

Those participants who reported to have left their country alone (23 cases), did so using family money, or with their own money and/through working, although they did not know the route and several note the presence of a person who accompanied them during the trip. Of these women, some whose origin was Guinea Conakry (10 cases) show several recurring stories: having paid for their trip by making hair braids 
or by asking for money along the way. These repeated accounts could be interpreted as a proposal of "constructed story" by the trafficking network, since it is unlikely that they would be able to make money in this manner in such a short time. Some of the participants note that once they made it to Morocco, they then made a living by cleaning houses. Finally, there is only one case of a woman, of Syrian origin, who notes that she was accompanied during the voyage by a direct family relative, her brother.

In relation to the above, but pointing to the indicators which are more related to «transportation, transfer, harbouring and receipt», 42 of the participants were lacking documentation, having lost it, or they were travelling without a passport, but with some documentation that they referred to as a student or identity card or, simply, with some false documentation that was provided by a person who had helped them to travel. This figure of some assistant along the route appears in a large number of explanations (81.6\%) provided by the participants, from the origin or during border crossings, and also taking different forms. For example, in the case of two of the women (a Guinean and one woman who claimed to be from Sudan), they mention men with whom they had sex in exchange for the payment of the border crossing, food or money. The young woman who claimed to be Sudanese explains it like this: "In Algeria they raped me and gave me some money. They hit you and if you don't want to, they can kill you".

However, in general terms, the most common of explanations is to find another of the possible "constructed stories» within their narratives, by which an unknown man, upon seeing her sorrowful weeping, helps her on the trip. In smaller numbers, some participants mention a family friend or a neighbour who accompanied them from their origin or helped them financially. One of the most remarkable facts in the stories of four participants is the reference to a Nigerian male who took them from Guinea to Morocco, and then urged them to take up prostitution. Further, the Nigerian male was demanding the payment of a debt under threat to the family of the study participants, and such cases are clearly marked as being human trafficking. Finally, one of the participants claimed to have travelled with her boyfriend after escaping from a forced marriage in Guinea Conakry, with the boyfriend managing the entire voyage. Finally, most of the women (61.22\%) recognised the existence of someone who was waiting for them at their target destination, with the most referenced locations being Madrid, Barcelona and Bilbao in Spain, or France.

Another of the indicators that were included in the Framework Protocol is the difficulty of handling the local language when the individual is at the destination location for a long period of time. This is self evident, considering that all of the study participants were newly arrived on the Spanish territory. It is noteworthy that one young woman from Guinea had difficulties in expressing herself in the colonial language of French of her country of origin. 
Finally, we highlight other indicators that are of importance in the present study, although they do not appear as such in the Framework Protocol. On the one hand, some of the women (20.40\%) noted their origin as being from an Anglophone country such as Malawi, Sudan, Liberia, Kenya and Eritrea (Table 1). Given the experience of the facilitator in Nigerian human trafficking together with a sound knowledge of Nigerian cultural traits, it was possible to find discursive signs that pointed to a high possibility of being women of that nationality, such as the use of the language or the allusion to foods that are typical of the region. In Spain, out of a total of 366 women who were identified as victims of trafficking in 2017. 212 had Nigerian nationality (State Attorney General's Office, 2017.). Moreover, Nigerian nationality was the second nationality of victims of trafficking for sexual exploitation purposes at the European level (EUROSTAT, 2016). This fact clearly places individuals of Nigerian nationality at risk in the detection of trafficking situations, as already reflected in several studies at the European level (Carling, 2006; Campana, 2015; Mai, 2016). On the other hand, of the 49 women who were interviewed, it was suspected that 3 of those women might be exercising the role of "controlling». That is, it appears on the networks with the highest share of power entrusted with the control of young women so that they do not flee or give information to the police (Women's Link Worldwide, 2014). These women were waiting for the youngest females, they wanted to enter the interviews, when the interviewee was leaving the interview and saw the "controller», the interviewee then lowered her head and walked behind her, etc.

In addition to the indicators for identification of victims of human trafficking that are presented in this paper, one of the results of the greatest interest in the use of this biographical narrative file was the fact that the questioning related to the health status of the study participant allowed the interview to gradually include indicators that were not previously designed. This is the case with female genital mutilation (experienced by more than half of women in this study); having fled before or living in a forced marriage (almost 35\%) or having suffered sexist or other violence at their origin (almost 37\% among them). These data could be even greater in size and relevance, since in the first interviews they were not taken into account and no specific question was asked about them.

Thus, the first stories about the continuous infections in the genital part or the pain when having sex when asked about the state of their body at the source, on the journey or at the time of the interview, permitted the participants to talk about the reasons, that is, the female genital mutilation. Another issue of relevance, as aforementioned, was precisely the importance of the reason for leaving the country in relation to the flight before a forced marriage (14 cases). Finally, 18 women report having experienced sexist violence at the source (physical aggres- 
sions and sexual rapes) or other types of violence by a family member, usually the father's new wife.

All of them are factors that, as evidenced by previous studies (Miguel, 2016, Goldberg, 2018), could be key factors when arguing a petition for international protection based on gender. However, as Clarence (2017) notes regarding the case of the United Kingdom or as Lesselier (2017) notes for France, it remains a challenge in the asylum procedures themselves. In this case, however, they allowed us to improve the proposal for establishing a record and adding new indicators that could make a proposal for a more comprehensive detection of states of vulnerability. Indeed, in addition to diagnosing these cases as being highly vulnerable, it would lead to the subsequent transfer to a specialised NGO where the individual could apply for asylum, provided the woman considers it so.

A final indicator of interest that emerged from this study was one of the most referenced issues in the literature on African migrations to Europe, that is, the aggressions against women along the migration route. Half of the study participants (51.02\%) note having experienced sexual violence on the journey in exchange for money or food; with abuse of power by the guide; or with direct violations, as is the case with 17 of the participants. These data are especially significant because of the taboo regarding the Muslim population, as was the case regarding the majority of young Guinean participants. One of these 25-year-old women noted the role of sexual assault at the different border crossings: «they rape you and then they let you cross the border». Another of the participants, also Guinean, noted the special harshness and violence of these violations: "Three men appeared. I put up a fight, but they beat me with a stick until I was unconscious. I lost some of my teeth and I almost lost an eye». Another participant witnessed the murder of a friend who attempted to defend her. Finally, it is particularly noteworthy that several noted Maghnia (border of Algeria with Morocco) as being one of the places where standardised aggressions are practiced. Maghnia is noted in several studies as an enclave of systematic human rights violations (Laacher, 2010; Euro-Mediterranean Human Rights Network, 2013; Bacheletet, 2018; Jorge and Antolinez, 2018).

The consequences for physical and psychological health are clear and some examples reflected in the literature are abortions using poisoned pills, alcohol or herbs; beating or cutting; extreme infection; birth in the forest or in contexts of poor health; or with more emphasis on emotions, the high rate regarding the presence of permanent fear in their discourses, as already described by the studies of Doctors Without Borders (2010, 2013). 


\section{The contribution of biographical narratives concerning care and integral health for the detection of situations of vulnerability}

Out of the 49 reports that were made, 40 indicated a favourable detection regarding individuals in a situation of high vulnerability. These reports were composed of a set of pictograms, words, simple phrases, lifelines and outlines of women who were admitted to both the management of the CETI and the Law Enforcements, and they caused the transfer of the said women to specialised centres where they were able to begin the processes of restoration. The speech constraints that have already been discussed in this paper make this a particularly remarkable result in terms of the development of intervention techniques that avoid the secondary victimisation that is so prominent in intervention processes with the groups that have suffered profound damage in their lives (Beristain, 1999; Orth, 2002; Calle, 2004).

We identify the work that has been undertaken in the present study, therefore, within a model of critical and humanistic intervention (Viscarret, 2011), that addresses the person as a complete human being under conditions of oppression. Similarly, this work promotes a comprehensive intervention for the protection of the person against these conditions of structural inequality. In this sense, from the humanist model (Rogers, 1995), the intervention proposal, although it has been limited in time, has been based at all times on the utmost respect for the person, allowing the file to narrate what the woman considered, without forcing her to give specific information that could cause the aforementioned secondary victimization. In this way, taking into account the constraining context that the CETI may be, we are committed to recognizing the agency of the participating women who freely decide and choose, as they have well demonstrated throughout their migration process. This decision framework could also be observed even in the development of the interviews where there were issues that some decided not to talk about and others did want to address. On the other hand, from the critical model (Morley and Macfarlane, 2011), a fundamental form of oppression in the cases of this study is patriarchy itself. This, as a system of domination, places women in conditions of greater vulnerability both in origin, journey and destination due to their own gender condition, and we have reflected this when addressing human trafficking or the various reasons for requesting asylum.

On the other hand, we place the methodology that we have used within the various diagnostic tools that are developed within the framework of social casework. In close relationship with other techniques such as biograms or timelines, we consider that this tool shows a specific contribution in terms of intervention regarding: 
a) The use of creative language as the basic proposal for use in the interview in this case. We propose adapting the intervention methodology, using imagination with respect to the diverse contexts and processes of the individual (Eisner, 2005). A broad communicative expression is also defended from the artistic tools and which, in this case, is articulated in the use of verbal language (oral and written) and visual narratives (pictograms and drawings).

b) The incarnated language where lived bodies and relational emotions are fundamental constituents of the multidimensional meanings of life experiences. In contrast to modern scientific objectivity, the «situated knowledge» that is generated by the protagonist is promoted in this form of intervention ( $\mathrm{Ha}$ raway, 1991). Further, it is encouraged that the person scrutinises, voluntarily and as far as she/he decides, in her/his memory and in everything that is in her/his body to locate the lived experiences from a positive perspective.

c) Lastly and importantly, the transversal approach to care that allows us to bring attention to an ethical commitment (Gilligan, 1985) whereby, on the one hand, the generation of spaces of trust, anonymity and security are a priority, and on the other hand, there is contemplation of the accompaniment towards the broad recovery processes of women. Finally, it is proposed that women's biographical narratives should be told from a perspective of care, rather than from perspectives of harm and human trafficking. It is the responsibility of the facilitator to detect in these accounts the indicators of human trafficking or any other situation(s) of vulnerability. Not only have we used this long pathway for intervention as a form of protection against the threats that women receive, we have also intended that this discursive action serves as a system of support in their process of restoration after everything that they have experienced. One must remember that at the end of this process of narration from the perspectives of health and care, it is planned to transfer to the medical team those important points that the woman wishes to discuss so that she can be treated. It is noteworthy that the health personnel must attend in an appropriate manner to the embodied demands and needs.

\section{LIMITATIONS OF THIS STUDY}

The main limitation of this study has been our access to a sample of a bounded population with profiles that have been previously determined by us, but those profiles have not allowed access to the diversity of the population that resided in the CETI in Ceuta in 2016. In that year, 2,412 individuals passed through the institution, out of 
which 1,898 were sub-Saharan in origin and 514 were Algerian in origin (APDHA, 2017). According to CEAR (2017), around 5\% of the said resident population were women, being a variable figure that depends upon the year and the period within a particular year. This sample of 49 women, whose profiles are shown in Table 1 , has not had claims of representativeness nor has it been an intentional sample since, as aforementioned, it has been derived from the commencement and development of this work.

On the other hand, we note as a limitation the time that was made available for conducting the interviews that have been the empirical basis of the material for the analysis. However, we also do recognise that this time limitation is what has allowed us to design our specific diagnostic sheet. Both for the intervention and for the research process itself, we aimed at compensating for this limitation with the triangulation of the information based on the methodological proposal itself, as well as the networking with both the technical team and the medical team of the CETI, and the staff of the NGOs that work in the centre, in order to be capable of corroborating their detections and reasons.

\section{CONCLUSION}

From the results of the present study, we present three conclusions of interest. Firstly, we reinforce the idea that focusing our detection work on a type of vulnerability, which in this case was the trafficking of human beings, may make other possible circumstances of interest invisible. Addressing other situations such as those that emerged in this study can allow: 1) diversifying the channels in order to initiate the processes of recognition and the defence of the rights of an individual and, 2) the same results confront us with the need for the design of itineraries, models and intervention protocols that take into account the multiplicity of circumstances that are experienced by the individual and, therefore, the diversity of profiles that break the mould of stereotypes.

Secondly, in this work we defend, based on the evidence of the practice carried out, the need for the revision of intervention approaches and techniques, in order to creatively contemplate the use of other forms of narrative production in accordance with the restoration processes; that would recognise and legitimise the lived experience as a carrier of fundamental knowledge in the matter; and that care can be established as a fundamental parameter. Such care, on the one hand, would be aimed at prioritising the protection of the rights of the individual, and on the other hand, such care would confirm the plot of her/his biographical stories, thus avoiding the possibility of re-victimisation. We consider the presented methodological experience in this study as a proposal that can be useful in the face of this challenge 
in border contexts with individuals in an irregular situation where detection and identification must also be rapid and agile in the face of deportation. Regarding the real-time experiences that show this potential, it is noteworthy that the file containing this methodology is still being used (and is always in the process of adaptation) by the social workers of the CETI in Ceuta who are in charge of the first reception interviews. Likewise, the file has been used in the CIE in Tenerife (Canary Islands; Spanish Autonomous Community) by the NGO Cruz Blanca Foundation and it has been adapted for work with male individuals in the same centre.

Finally, we consider that the present study has two contributions that can be considered to be of some relevance. Firstly, we have been able to generate knowledge from the practice of social intervention which is of great value for the praxis of social work (Caparrós, Carbonero and Raya, 2016). Secondly, we highlight this collaborative work between universities and social organisations, thanks to which access to knowledge on the differentiated reality of migrant women in relation to men has been achieved. This is a challenge for which there is still much academic research to be made in the field of migration on the southern European border, and also regarding the social intervention process itself with respect to that group.

\section{REFERENCES}

1. Amnesty International (2015). Fear and fences. Europe's approach to keeping refugees at bay. Retrieved from: https://www.amnesty.org/download/Documents/EUR0325442015ENGLISH.PDF (11.1.2019).

2. Amnesty International (2016). En Tierra de Nadie. La situación de las personas refugiadas y migrantes en Ceuta y Melilla (In No crops of nobody. The situation of refugees and migrants in Ceuta and Melilla). Retrieved from: https:// www.es.amnesty.org/uploads/media/Informe-Ceuta-y-Melilla_FINAL-1.pdf (4.4.2019).

3. Antolinez, I. \& Jorge, E. (2018). Migrant women and human trafficking for purpose of sexual exploitation on Europe's southern frontier: A proposal for methodology in action research. In Bermúdez-Figueroa, E. \& Roca, B. (eds.), Andalusia. History, society and diversity. New Haupage: Nova Science Publishers, 231-256.

4. APDHA (2016, 2017, 2018, 2019). Derechos Humanos en la Frontera Sur [Human rights on the southern border]. Retrieved from: www.apdha.org/category/ seccion/informes. (2/11/2018).

5. Bachelet, S. (2018). 'Wasting mbeng': Adventure and trust amongst sub-Saharan migrants in Morocco. Ethnos, 849-866. https://doi.org/10.1080/00141844.201 8.1537298. 
6. Baylos, A. (2015). Desigualdad, vulnerabilidad y precariedad en el análisis jurídico de género [Inequality, vulnerability and precariousness in the legal analysis of gender]. Revista de Derecho Social, 72, 43-57.

7. Beristain, A. (1999). Criminología y Victimología [Criminology and victimology]. Colombia: Leyer.

8. Calle, S. (2004). Consideraciones sobre la victimización secundaria en la atención social a las víctimas de la violencia de género [Considerations on secondary victimization in social care for victims of gender violence]. Barcelona: Ayuntamiento de l'Hospitalet de Llobregat.

9. Campana, P. (2016). The structure of human trafficking: Lifting the bonnet on a Nigerian transnational network. The British Journal of Criminology, 56 (1), 68-86. https://doi.org/10.1093/bjc/azv027.

10. Caparrós, N., Carbonero, D. \& Raya, E. (2016). Construir conocimiento desde la práctica: Ejemplos de sistematización en Trabajo Social [Build knowledge from practice: Examples of systematization in social work]. Interacción y Perspectiva, 7 (1), 61-79.

11. Carling, J. (2006). Migration, human smuggling and trafficking from nigeria to europe. Volume, 23. International Organization for Migration.

12. CEAR (2014). El camino sin fin: Huellas de las mujeres en la frontera sur. Informe de la misión de observación de derechos humanos [The endless road: Women's footprints on the southern border. Human rights observation mission report]. Retrieved from: https://www.cear-euskadi.org/wp-content/uploads/Informe-Melilla-cast.pdf . (03.06.2019).

13. CEAR (2017). Refugiados y migrantes en España. Los muros invisibles tras la frontera sur [Refugees and migrants in Spain. The invisible walls behind the southern border]. Retrieved from: www.cera.es/wp-content/uploads/2017/06/ Informe-Anual-CEAR-2017.pdf . (03.06.2019.).

14. Charmaz, K. (2005). Grounded theory in the 21st Century. In: Denzin, N. K. \& Lincoln, Y. S. (eds.), The SAGE handbook of qualitative research. London: Sage Publication, 507-535.

15. Clarence, E. (2017). Ignored and isolated: Women and asylum policy in the United Kingdom. In: Freedman, J. (ed.), Gender and insecurity migrant women in Europe. London: Routledge, 19-34.

16. Conseil National des Droits de l'Homme (2013). Extranjeros y derechos humanos en Marruecos para una política migratoria y de asilo radicalmente nueva [Foreigners and human rights in Morocco for a radically new immigration and asylum policy]. Retrieved from: https://www.cndh.ma/sites/default/files/ cndh_-_immigration_esp-.pdf (05.04.2018.). 
17. De Haas, H. (2008). Irregular migration from West Africa to the Maghreb and the European Union: An overview of recent trends. IOM Report.

18. Doctors without borders (2013). Violence, vulnerability and migration: Blocked at the gates of Europe. A Report on Sub-Saharan migrants in irregular situation in Morocco. MSF Report.

19. Doctors without borders (2010). Sexual violence and migration. The hidden reality of Sub-Saharan women trapped in Morocco en route to Europe. MSF report.

20. Eisner, E. W. (2004). El arte y la creación de la mente: El papel de las artes visuales en la transformación de la conciencia [Art and the creation of the mind: the role of visual arts in the transformation of consciousness]. Barcelona: Paidós.

21. Euro-Mediterranean Human Rights Network (2013). Maghnia: Crossing the uncrossable border - mission report on the vulnerability of Sub-Saharan migrants and refugees at the Algerian-Moroccan border. Copenhagen: Euro-Mediterranean human rights network.

22. EUROSTAT (2016). Trafficking in human beings in the European Union. Retrieved from: https://ec.europa.eu/anti-trafficking/sites/antitrafficking/files/situational_report_trafficking_in_human_beings-_europol.pdf (10.10.2018.).

23. Fineman, M.A. (2010). The vulnerable subject and the responsive state. Emory Law Journal, 60 (2), 251-275.

24. Frelick, B.; Kysel, I.M. \& Podkul, J. (2016). The impact of externalization of migration controls on the rights of asylum seekers and other migrants. Journal on Migration and Human Security, 4 (4), 190-220.

25. García de Diego, M. J. (2010). «Bajo el casco de Hades»: Menores migrantes no acompañadas como posibles víctimas de trata y su triple invisibilización [«Under the helmet of Hadesı: Unaccompanied migrant children as possible victims of trafficking and their triple invisibility]. Migraciones, 28, 199-223.

26. Gibbs, G. (2012). El análisis de datos cualitativos en investigación cualitativa [The analysis of qualitative data in qualitative research]. Madrid: Morata.

27. Gilligan, C. (1985). La moral y la teoría: Psicología del desarrollo femenino (Morality and theory: Psychology of female development). México: Fondo de Cultura Económica.

28. Goldberg, P. (2018). Where in the world is safety for me? Women fleeing gender-based persecution. In: Peters, J.S. \& Wolper, A. (eds.), Women's Rights, Human Rights: International Feminist Perspectives. New York and London: Routledge, 345-355.

29. Hadjab, H. (2017). Las nuevas generaciones de personas menores migrantes [The new generations of migrant minors]. Unpublished doctoral thesis. University of Granada. 
30. Haraway, D. (1991). Simians, cyborgs and women: The reinvention of nature. New York: Routledge.

31. Jorge, E. \& Antolinez, I. (2018). Rebuscando los miedos fabricados en la ruta migratoria con jóvenes y mujeres nigerianas que cruzan la frontera sur española [Searching for the fears manufactured on the migration route with Nigerian youth and women who cross the southern Spanish border]. In: Cortés, A. \& Manjarrez, J. (eds.), Género, Migraciones y Derechos Humanos. Barcelona: Bellaterra, 219-317.

32. Laacher S. (2010). Les violences faites aux femmes pendant leur voyage clandestin: Algérie, France, Espagne, Maroc (Violence against women during their clandestine journey: Algeria, France, Spain, Morocco). Research Paper No. 188, United Nations High Commissioner for Refugees.

33. Lesselier, C. (2017). Women migrants and asylum seekers in France: Inequality and dependence. In: Freedman, J. (ed.), Gender and insecurity: Migrant women in Europe. London: Routledge, 35-54.

34. Mai, N. (2016). 'Too Much Suffering': Understanding the interplay between migration, bounded exploitation and trafficking through Nigerian sex workers experiences. Sociological Research Online, 21 (4), 1-14. https://doi.org/10.5153/ sro.4158.

35. McAdams, D.P. (1993). The stories we live by: Personal myths and the making of the self. New York: Guilford Press.

36. Migreurop and GADEM (2016). Ceuta \& Melilla. Centros de selección a cielo abierto a las puertas de África. [Ceuta \& Melilla. Opencast selection centers at the gates of Africa]. Retrieved from: http://www.migreurop.org/IMG/pdf/ceuta_melilla_centros_de_seleccion_definitivo_1_.compressed.pdf (10/02/2017).

37. Miguel, C. (2016). Refugiadas. Una mirada feminista al derecho internacional. [Refugees. A feminist look at international law]. Madrid: Catarata.

38. Morcillo, J.M., de la Fuente, Y. \& Sotomayor, E.M. (2017). Género y procesos de exclusión social en el tránsito entre Marruecos y Andalucía [Gender and social exclusion processes in transit between Morocco and Andalusia]. Azarbe. Revista Internacional de Trabajo Social y Bienestar, 6, 27-36.

39. Morley, Ch. \& Macfarlane, S. (2011). The Nexus between feminism and postmodernism: Still a central concern for critical social work. British Journal of Social Work, 1-19. https://doi.org/10.1093/bjsw/bcr107.

40. Morondo, D. (2016). A new paradigm for equality? Vulnerability as human condition and as a state of defencelessness. Cuadernos Electrónicos de Filosofía del Derecho, 34, 205-221. https://doi.org/10.7203/CEFD.34.8916.

41. Naudé, W. (2010). The determinants of migration from sub-Saharan African countries. Journal of African Economies, Centre for the Study of African Economies (CSAE), 19 (3), 330-356. 
42. Noddings, N. (1988). An ethic of caring and its implications arrangements. American Journal of Education, 96 (2), 215-230.

43. Omorodion, F. (2009). Vulnerability of Nigerian secondary school to human sex trafficking in Nigeria. African Journal of Reproductive Health, 13(2), 33-48.

44. Orth, U. (2002). Secondary victimization of crime victims by criminal proceedings. Social Justice Research, 15 (4), 313-325.

45. Papageorgiou, V. (2018). The externalization of European borders. Research paper No. 23. Center for International Strategic Analyses (KEDISA).

46. Rogers, C. (1995). On becoming a person. A therapist's view of psychotherapy. Houghton Mifflin Harcourt: Mariner Books.

47. Rais, M. (2016). European Union readmission agreements. Forced Migration Review, 51. Retrieved from: http://www.fmreview.org/sites/fmr/files/FMRdownloads/en/destination-europe/rais.pdf (10.4.2019.).

48. Spanish Ombudsman (2012). La trata de seres humanos en España: víctimas invisibles [Trafficking in human beings in Spain: invisible victims]. Madrid: Author.

49. Spanish Ombudsman (2016). Informe Anual 2016. (Annual Report 2016). Retrieved from: https://www.defensordelpueblo.es/informe-anual/informe-anual-2016/ (2.2.2019.).

50. State Attorney General's Office (2017). Memoria de actividad [Activity memory]. Madrid.

51. Tuwor, T. \& Sossou, M.A. (2008). Gender discrimination and education in West Africa: strategies for maintaining girls in school. International Journal of Inclusive Education, 12 (4), 363-379.

52. UNHCR (2009). Guidelines on international protection: Child asylum claims under articles 1(A)2 and 1(F) of the 1951 Convention and/or 1967 Protocol relating to the status of refugees. Retrieved from: https://www.refworld.org/docid/4b2f4f6d2. html (11.10.2018.).

53. Viscarret, J. (2011). Modelos de intervención en trabajo social [Models of intervention in social work]. Madrid: Alianza.

54. Women's Link Worldwide (2014). Trafficking of Nigerian Women and Girls: Slavery across Borders and Prejudices. Retrieved from: https://www.womenslinkworldwide.org/en/files/1355/trafficking-of-nigerian-women-and-girls-slavery-across-borders-and-prejudices.pdf (13.3.2019.). 
Inmaculada Antolinez-Domínguez

Zavod za socijalni rad

Odsjek za rad, pravo i socijalnu sigurnost

Sveučilište u Cadizu, Španjolska

Esperanza Jorge-Barbuzano

Sveučilište u Cádizu, Španjolska

\section{IZAZOVI U IDENTIFICIRANJU RANJIVOSTI MIGRANTICA NA JUŽNOJ GRANICI EUROPE: DOPRINOSI IZ BIOGRAFSKIH NARATIVA}

\section{SAŽETAK}

U 1980-tima južna granica Španjolske postala je jedna od južnih granica Europske Unije nakon što je Španjolska ušla u Europsku ekonomsku zajednicu (EEZ). Na afričkom kontinentu španjolski gradovi Ceuta i Melilla koji graniče s Marokom fizički su odvojeni od Španjolske Sredozemnim morem. Ta su dva grada postala povlaštene enklave za imigracijsku kontrolu, ali i za otkrivanje ranjivih uvjeta migrantske populacije. Rad ima dvostruki cilj: opisati akcijsko istraživanje koje je razvio Centar za privremeni smještaj migranata u Ceuti i analizirati 49 biografskih intervjua sa ženama koje borave u Centru u okviru spomenutog akcijskog istraživanja. Rezultati pokazuju različitost situacija ranjivosti u kojima se migrantice mogu naći u kontekstu granice. Stoga je važno preispitati intervencije kako bi se izbjegla sekundarna viktimizacija u sklopu kritičkih i humanističkih modela intervencije. Rad se bavi kreiranjem instrumenta za biografske narative iz perspektive integralnog zdravlja i skrbi.

Ključne riječi: migrantice; ranjivost; južna granica Europe; biografski narativi

\section{(c) (1) $(\Theta$}

Međunarodna licenca / International License:

Creative Commons Attribution-NonCommercial-NoDerivatives 4.0. 